Citation: Jorge Mota, Rui Costa, António Moreira, Silvana Serrão, Carlos Costa (2021) Competitiveness framework to support regional-level decisionmaking in the wine industry: a systematic literature review. Wine Economics and Policy 10(2): 29-40. doi: 10.36253/ wep-10131

Copyright: ( 2021 Jorge Mota, Rui Costa, António Moreira, Silvana Serrão, Carlos Costa. This is an open access, peer-reviewed article published by Firenze University Press (http://www. fupress.com/wep) and distributed under the terms of the Creative Commons Attribution License, which permits unrestricted use, distribution, and reproduction in any medium, provided the original author and source are credited.

Data Availability Statement: All relevant data are within the paper and its Supporting Information files.

Competing Interests: The Author(s) declare(s) no conflict of interest.

\section{Competitiveness framework to support regional-level decision-making in the wine industry: a systematic literature review}

\author{
Jorge Mota*, Rui Costa, António Moreira, Silvana Serrão, Carlos \\ Costa \\ Department of Economics Management Industrial Engineering and Tourism, University \\ of Aveiro, Aveiro, Portugal and Governance Competitiveness and Public Policies Research \\ Unit, University of Aveiro, Aveiro, Portugal, Email: jorgemota@ua.pt; ruicosta@ua.pt; \\ amoreira@ua.pt; silvana.serrao@ua.pt; ccosta@ua.pt \\ ${ }^{*}$ Corresponding author.
}

\begin{abstract}
This study aims to identify the main performance indicators and group them in dimensions within a regional competitiveness framework to support decisionmaking in the wine industry. For this research, a systematic literature review (SLR) was conducted in the Scopus database. There is a limited number of studies identifying indicators with impact on the performance of wine regions, and even fewer studies including indicators in an integrated approach to measure the different dimensions of wine regions' performance. From a set of 85 papers, only 9 studies related to performance indicators with a specific focus on the regional level were considered. We document that under a convention framework, economic and territorial indicators cover $84.90 \%$ of all SLR indicators analysed, and under a regional competitiveness framework, infrastructure and innovation and intellectual capital indicators fill $81.25 \%$ of all the indicators. As this group of indicators is limited to a set of sub-dimensions, we found that several groups of indicators are misrepresented, such as the ones related to human and socio-cultural capital areas, which play a crucial role in the regional competitiveness of the wine industry. This paper contributes to the literature identifying indicators according to convention and regional competitiveness frameworks in three dimensions - economic, environmental and territorial dimensions and five main areas - productive capital, human capital, socio-cultural capital, infrastructure and intellectual capital. These indicators are to be used at regional-level to support decision-making in the wine industry. For regional entities, it discloses the most pertinent indicators which need improvement to craft regional strategies. This framework is of added value for policymakers to customize their support programmes so that specific producers can enhance their competitive strategies. It could also be deployed in teaching programmes as a tool to address the importance of aligning different types of indicators to achieve better performance in the wine industry.
\end{abstract}

Keywords: regional competitiveness, performance indicator, wine industry, competitiveness framework, systematic literature review. 


\section{INTRODUCTION}

Wine production constitutes one of the most ancient industries in the agri-food sector, providing important economic revenues for many countries and regions worldwide [1, 2]. The international trade of wine has mainly been dominated by three European countries - Italy, Spain, and France - which together export 57.1 million hectoliters (mhl) and represent $54 \%$ of the global market [3]. The growth of the wine industry highlights the importance of ensuring a competitive industry through the entire supply chain and in all its dimensions [4].

Wine-producing firms in Bordeaux, La Rioja, Tuscany, and Douro, among others, leverage their reputation supported by their association with the region in which they operate [5]. Today's world requires that businesses in a specific region should focus not only on their internal development and success, but also on the development of the social, economic, and environmental conditions of the contexts in which they operate [6].

Regional competitiveness, which has been attracting more attention due to its importance for economic growth and wealth creation, lies between the business and the national levels of competitiveness [e.g., 7, 8, 9].

Competitiveness frameworks can be considered as a way for wine territories to systematize current practices or innovative entrepreneurial ways to improve wine management and promote innovation processes. Wine regions have been creating their own frameworks, presented as national (or regional) programmes to be implemented in their contexts and deal with local issues. Additionally, these frameworks support the positioning of the wine territory [10].

Convention theory has been used as an explanatory framework in agri-food sectors and regions worldwide in order to understand the current trends in the agri-food system [11] and also analyse a wide range of cases [12] in various territories. Thus, one perspective to frame competitiveness in the wine regions is based on convention theory.

In regional competitiveness, the intervening factors, albeit resources that lie outside business processes, can be summarized as various types of capital, such as productive, human, social-cultural, infrastructure and intellectual. According to the World Economic Forum (WEF) Competitiveness Global Index (CGI) and the European Commission (EC) Regional Competitiveness Index (RCI), regional competitiveness should include two additional dimensions: efficiency (higher education and training; market size; labour markets); and innovation (technological readiness; business sophistication; innovation). According to Lengyel [13], the enhancement of regional competitiveness may follow a pyramid model. At the top sits the objective of regional competitiveness: quality of life and standard of living. On the bottom are the success determinants related to human/ intellectual capital (skills of the workforce, innovative activity), infrastructure (regional accessibility, environment), socio-cultural (regional identity, social structure, decision centres), economic structure. In the middle are the development factors (foreign direct investment, small and medium-sized enterprises, institutions and social capital, research, and technological development) which are related to the basic categories (labour productivity, employment rate, regional performance/gross regional product).

Despite there being several studies associated with performance in the wine business [14], there is a lack of emphasis on the development of studies that contain or summarize the major indicators applied in a regional context (in this research, 9 of the 85 selected studies). These are crucial for the identification of commonly used indicators for monitoring the wine industry [15]. Nevertheless, we can observe a growing interest and development for regional studies in recent years [e.g., 16, $17,18,19]$ and the indicators cited in these studies refer mostly to protected designations of origin (7 of 9 studies apply to Spanish protected designations of origin).

Regional indicators can contribute to improving knowledge about the decision-making processes of wine regions and consequently to the design of policy programmes to support the competitiveness of this industry. Furthermore, they could help to attain a clear view of the potential impacts associated with their strategy and, consequently, to adjust them in the future [20].

In line with the concept of competitiveness, traditionally defined as the intersection of economic, environmental, and territorial dimensions, we believe it is crucial to adopt a global approach that combines the interactions of these dimensions. Nevertheless, when studies adopt a global approach regarding performance, we note that the territorial dimension is not given its proper importance. Despite its relevance in the wine industry, the territory plays a substantial role in economic, environmental, and infrastructural terms, among others, that are not properly addressed. As a result, we believe that all information must be integrated to obtain a better understanding of the main wine territorial/ regional competitiveness factors. This gap in the literature could be filled as a starting point to study performance in the wine industry at the regional level, including economic, environmental, and territorial dimensions. 
With the aim of identifying the main performance indicators used at a regional level to support decisionmaking in the wine industry, a systematic literature review (SLR) was carried out on papers published in the Scopus database from 2009 to 2019.

This paper contributes to the literature by: (i) identifying indicators that can be easily adopted by wine regions, to make comparisons and support decisionmaking processes; (ii) grouping the indicators into three dimensions, based on an inductive thematic analysis and interpretative synthesis - territorial, economic and environmental - and five main areas - productive capital, human capital, social-cultural capital, infrastructure and intellectual capital; and (iii) structuring a regional competitiveness framework of analysis for the performance of wine-producing regions.

This present paper is organized as follows: after this introduction, section 2 describes the research methodology and section 3 discusses the research results. Conclusions, practical implications, and future research recommendations of the study are presented in section 4.

\section{RESEARCH METHODOLOGY}

Wine as a research topic continues to address a plethora of diverse contexts (Bonn et al., 2017). In order to analyse topics, patterns and/or development of a specific area in the wine industry, an SLR seems an appropriate technique for the purpose of this study.

SLRs consist of the identification, selection, analysis, and synthesis of existing research on a specific topic and its presentation to display what is known and not known about the topic [21]. The main advantages of SLRs are transparency in data collection and synthesis, which results in a higher level of objectivity and reproducibility [22]. SLRs have also other advantages: they provide an overview of areas in which the research is disparate and interdisciplinary; they provide an overview of a certain issue or research problem; they identify gaps in research; they provide the basis for building a new conceptual model or theory; and they can be valuable when aiming to map the development of a particular research over time [23]. An effective and well-conducted review as a research method can provide new directions and challenges for future research studies [24].

In this research, the papers analysed in the SLR cover several performance indicators to support decisionmaking in wine regions. In order to identify the main indicators and frameworks used in the analyses of the wine industry, an SLR was carried out following the pro- tocol proposed by Tranfield et al. [22], which comprises three main stages: a) planning; b) conducting; and c) reporting and disseminating the results.

For a credible outcome, the use of scholarly, top peerreviewed, published journal articles is highly important $[25,26]$. Based on the quality, plurality and relevance of its scholarly reputed journals, the Scopus database was adopted. One of the particularities of the Scopus database is that is allows researchers to analyse and easily compare literature review outputs through a comprehensive and easy search customization procedure that allows the inclusion/exclusion of search word criteria.

In order to properly plan the SLR, it is mandatory to define the objective of the SLR, which in this paper is to identify the main performance indicators used at regional level to support decision-making in the wine industry. To conduct the review, it is necessary to properly use explicit inclusion search criteria to identify relevant literature. This needs to be assessed following exclusion criteria, so that only the relevant studies are incorporated and then fine graining the quality of the studies reviewed to strengthen the quality of the findings. The final stage involves reporting and getting the evidence into practice.

The planning of the review involved the definition of the following search words searched by title, keywords and abstract: 'indicator', 'performance indicator', 'wine', 'wine sector', 'wine industry' and 'winer*'. The information of the inclusion criteria is as follows:

i. Publication date: 2009-2019

ii. Language: documents written in English, French, Portuguese, and Spanish.

iii. Type of document: articles, reviews, articles in press, conference papers and conference reviews.

As no exclusion criteria were defined, 464 documents that contained one or more search terms were considered in the analysis. Table 1 summarizes the research method applied in the Scopus database.

Publication citation data - author(s), title, date, keywords and abstract - were downloaded for each document published in Scopus since 2009. The data were then imported into Microsoft Excel for further cleaning and processing to ensure all information elements had successfully been downloaded.

A cross-sectional reading of the 464 results was carried out to select publications whose title, abstract, keywords would suggest the presence of indicators related to the wine industry. To increase the reliability of the selection, the documents were evaluated by three researchers and doubts and disagreements were discussed until consensus was achieved. The documents were included if all reviewers agreed. 
Table 1. Research method in the Scopus database.

\begin{tabular}{ll}
\hline 3. Scope of research & \multicolumn{1}{c}{ Scopus database } \\
\hline $\begin{array}{l}\text { Keywords } \\
\text { Queries (TITLE-ABS-KEY) }\end{array}$ & TITLE-ABS-KEY ("indicator*" OR "performance indicator*") AND ("wine" OR "wine sector" OR "wine \\
industry" OR "winer*)) \\
Documents in English, French, Portuguese, and Spanish between 2009-2019; \\
Type of document: articles, reviews, articles in press, conference papers and conference reviews. \\
Then criteria \\
$\begin{array}{l}\text { The research was carried out on two different dates, confirming the same results. The steps in the two searches } \\
\text { were: (i) access to the database; (ii) consultation; (iii) application of the inclusion criteria and (iv) export the } \\
\text { results to Excel. } \\
\text { The research achieved } 1053 \text { results before the application of the criteria stated above. }\end{array}$
\end{tabular}

After selecting the most relevant studies for the purpose of this research (85 publications), we examined and selected only the documents that contain indicators from a regional perspective ( 9 results). Figure 1 synthesizes the methodological process adopted during the identification and selection of documents.

The following section aims to answer the main purpose of this study. The following three specific steps were thus defined: i) to present the main descriptive results of the selected studies (date of publication; publication source and geographical location); ii) to examine which indicators are proposed in frameworks; and iii) establish how the literature classifies them. As such, it was possible to map the state of the art of the main indicators analysed. Following Braun and Clarke [27] and Silva and Moreira [26], we sought to organize the literature in patterns of topics involving inductive thematic analysis - indicators, e.g., average size of the winery per region, number of wineries per region, number of brands per region, surface of the vineyard, surface area planted with high yielding grape varieties, and percentage of young wines. Based on Jones et al. [28] and Ribau et al. [29], following an interpretative synthesis, we managed to cluster the papers in related topics or indicators and aggregated them in higher order classes that we call categories - economic, environmental, and territorial - and five main areas - productive capital, human capital, socio-cultural capital, infrastructure, and intellectual capital.

\section{RESULTS}

Despite the growing number of studies carried out in the wine industry and given the multiplicity of themes present in the literature, only a total of nine theoretical and empirical papers present regional level

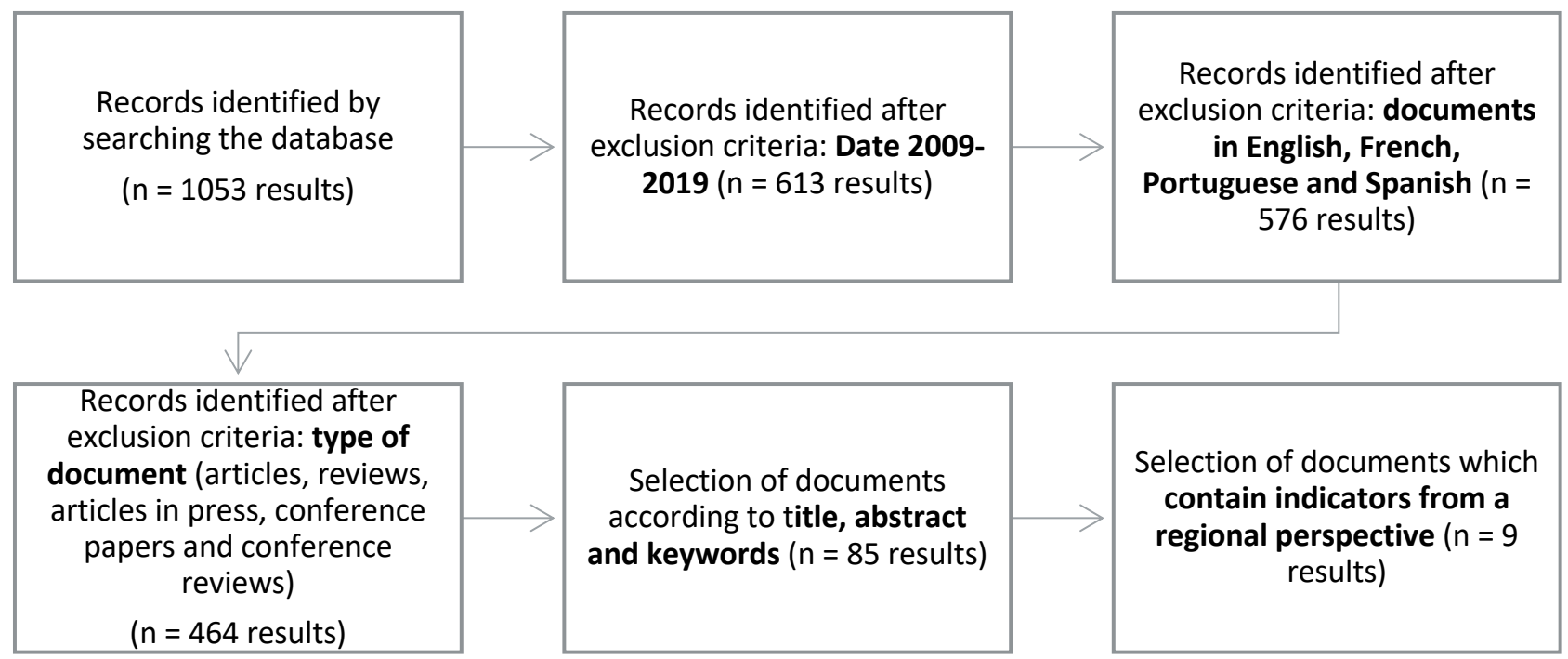

Figure 1. Methodological process. 
performance indicators according to the aim of this research.

\section{Date of publication}

The survey reveals a growing interest and development of studies in recent years as most of the studies identified were published between 2015-2019 (66.7\%), reinforcing the relevance of the thematic studied. Table 2 summarizes the number of publications per year.

\section{Publication source}

The papers were published in eight different journals, as shown in Table 3, which is a clear indication of how scattered the publication outlets were in the last decade. However, most sources of publication are related to geography or agro-environmental issues. Regarding publications per number of authors, as demonstrated in Figure 2 , most were carried out by two authors (4 of 9 studies).

\section{Geographical location}

The papers feature limited geographic dispersion, demonstrating that the subject matter is studied pre-

Table 2. Number of publications per year.

\begin{tabular}{lcc}
\hline Year & Publications (N) & Percentage \\
\hline 2009 & 1 & $11.1 \%$ \\
2011 & 1 & $11.1 \%$ \\
2014 & 1 & $11.1 \%$ \\
2015 & 1 & $11.1 \%$ \\
2017 & 3 & $33.3 \%$ \\
2018 & 2 & $22.2 \%$ \\
Total & 9 & $100.00 \%$ \\
\hline
\end{tabular}

Table 3. Main sources of publication.

\begin{tabular}{lc}
\hline Sources of Publication & N \\
\hline Cuadernos Geográficos & 2 \\
Géographie Economie Société & 1 \\
Geoforum & 1 \\
Mundo Agrario & 1 \\
Annales de Geographie & 1 \\
Boletín de la Asociación de Geógrafos Españoles & 1 \\
Economía Agraria y Recursos Naturales & 1 \\
Applied Ecology and Environmental Research & 1
\end{tabular}

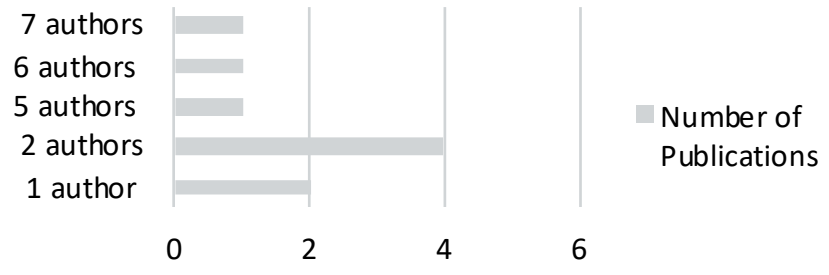

Figure 2. Publications per number of authors.

dominantly in European countries. This research also confirms that the nine publications were applied in one specific country, more precisely in Spain $(n=7)$, Argentina $(\mathrm{n}=1)$ and Hungary $(\mathrm{n}=1)$.

Relating to wine regions, we observe growing interest and development for regional studies [e.g., 16, 17, 18, 19, 30]. In addition to the nature of the studies, these indicators refer mostly to wine with protected designation of origin. In this sense, Table 4 summarizes the selected studies according to geographical coverage and sample.

Comparative studies were observed in this review. On examining Table 4, we identified studies applied in different regions or protected designations of origin (PDO). For instance, Sánchez-Hernández et al. [18] include 16 protected designations of origin in their research, whereas Climent-López and Sánchez Hernández [11] and Esteban-Rodriguez and Climent-López [30] analyse a sample of all the Spanish wine PDOs. The same pattern is followed by Esteban-Rodríguez [19] and Esteban-Rodríguez and Climent-López [16] as they considered all wine PDOs present in Spanish territory. On the other hand, Esteban-Rodriguez and Climent-López [17] analyse 88 of 90 PDOs. Finally, De Villanueva [31] characterizes the wine industry located in the province of Mendoza, Argentina, and Szenteleki et al. [32] include three Hungarian wine regions: Etyek-Budai; Kunsági and Mátrai (including 17 sub-regions).

\section{Indicators and frameworks: a regional perspective}

The use of frameworks and indicators is a way to read and interpret the situation, simultaneously allowing a comparison of contexts over time [10]. A correct use of indicators may be applied to determine the critical areas of intervention to ensure competitive viticulture and may represent a decision-making tool to support wine regional entities, winemakers, and other related professionals [33]. One challenge is the selection of the most representative performance indicators to be included in a framework for wine regions. As a result of the SLR carried out in this paper, a list with 112 regional indicators was generated, which were based exclusively on 
Table 4. Studies by their geographical coverage and sample.

\begin{tabular}{|c|c|c|}
\hline References & $\begin{array}{l}\text { Countries where survey } \\
\text { was conducted }\end{array}$ & Geographical Coverage \\
\hline $\begin{array}{l}\text { Climent-López and } \\
\text { Sánchez Hernández [11] }\end{array}$ & Spain & $\begin{array}{l}12 \text { PDO wine districts: Arlanza, Arribes, Bierzo, Calatayud, Campo de Borja, Cariñena, } \\
\text { Cigales, Ribera del Duero, Rueda, Somontano, Tierra de León and Toro. }\end{array}$ \\
\hline Climent-López et al. [12] & Spain & $\begin{array}{l}16 \text { PDO: Arlanza, Arribes, Bierzo, Calatayud, Campo de Borja, Cariñena, Cigales, } \\
\text { Mondéjar, Ribera del Duero, Rueda, Somontano, Tierra de León, Tierra del Vino de } \\
\text { Zamora, Toro, Uclés, Vinos de Madrid. }\end{array}$ \\
\hline De Villanueva [31] & Argentina & Province of Mendoza \\
\hline $\begin{array}{l}\text { Esteban-Rodriguez and } \\
\text { Climent-López [17] }\end{array}$ & Spain & 88 protected designations of origin \\
\hline $\begin{array}{l}\text { Esteban-Rodriguez and } \\
\text { Climent-López [30] }\end{array}$ & Spain & $\begin{array}{l}\text { All Spanish wine PDOs: Rioja, Ribera del Duerao, Montilla-Morilles, Vinos de Madrid, } \\
\text { Terra Alta, Penedés, Costers del Segre, Bierzo, Tierra del Vino de Zamora, Pago Guijoso, } \\
\text { Pago Dominio de Valdepusa and Cigales. }\end{array}$ \\
\hline Esteban-Rodríguez [19] & Spain & 90 protected designation of origin \\
\hline $\begin{array}{l}\text { Esteban-Rodriguez and } \\
\text { Climent-López [16] }\end{array}$ & Spain & 90 protected designation of origin \\
\hline $\begin{array}{l}\text { Sánchez-Hernández et } \\
\text { al. [18] }\end{array}$ & Spain & $\begin{array}{l}3 \text { regions in } 16 \text { Spanish wine districts: Aragón (Catalayud; Campo de Borja; Cariñena; } \\
\text { Somontano); Castilla y León (Arlanza; Arribes; Bierzo; Cigales;Ribera del Duero; Rueda; } \\
\text { Tierras de León; Tierra del Vino de Zamora; Toro); Castilla-La Mancha (Mondéjar; } \\
\text { Uclés) and Comunidad de Madrid (Vinos de Madrid). }\end{array}$ \\
\hline Szenteleki et al. [32] & Hungary & Etyek-Budai; Kunsági and Mátrai wine regions (includes 17 sub-regions) \\
\hline
\end{tabular}

the articles under analysis and related exclusively to the presence of regional indicators in them.

To document which indicators are included in the frameworks, as well as how the research classified them, it is crucial to specify the criteria applied in this research. Bearing in mind the articles selected through the SLR, 'indicator classification' was considered to be when: i) the authors had explicit categories/dimensions; and ii) even though not explicitly mentioned, it was possible to ascertain an indicator category/classification inductively generated according to the researchers' perspective.

The identification of the dimensions/categories was explicit in the cases of Climent-López and SánchezHernández [11] and Climent-López et al. [12], in which the indicators followed quality conventions: industrial, commercial, domestic, civic, public and ecological. Despite addressing the same study field, Esteban-Rodríguez and Climent-López [30], Esteban-Rodríguez [19] and Esteban-Rodríguez and Climent-López [16] characterize the indicators based on different dimensions: market, technology and competition type. Conversely, Sánchez-Hernández et al. [18] classify the indicators into products or resources and, finally, Szenteleki et al. [32] categorize them as climate-based indicators. The second case occurs, for example in Esteban-Rodríguez and Climent-López [17] in which, although the presented indicators are not explicitly classified, the combination of them makes it possible to set suitable indicators to identify different production models of PDOs in Spain.
Convention theory has been used as an explanatory framework in agri-food sector studies, including the wine industry, and provides comparative studies through several wine-producing areas with PDO label. Despite the limited number of papers that address regional performance indicators, it is clearly possible to conclude that they use six different types of classification $[12,11,19,16,17,30]$. These are synthetized in Table 5, as well as the number of indicators and frameworks.

According to Table 5, Climent-López et al. [12] classify the indicators into five quality conventions - industrial, commercial, domestic, civic and public. Despite using the same classification of indicators, ClimentLópez and Sánchez-Hernández [11] introduces a sixth quality convention - ecological. Despite that, while the previous authors characterize the indicators according to six quality conventions, which are an aggregation of indicators, Esteban-Rodríguez and Climent-López [16, 30] and Esteban-Rodríguez [19] categorize the indicators simultaneously according to the following dimensions - market, technology, and competition type -as part of the framework. On the same logic, Sánchez-Hernandez et al. [18] aggregate 21 indicators according to product and resources and Szenteleki et al. [32] analyse 11 indicators from the perspective of climatic conditions, which are both integrated into a framework. Finally, there are cases such as De Villanueva [31] where no classification or framework is observed at all, and the indicators are scattered. 
Table 5. Number of indicators with their classification and framework.

\begin{tabular}{lccll}
\hline Authors & Indicators & Framework & \multicolumn{1}{c}{ Classification } \\
\hline Climent-López and Sánchez-Hernández [11] & 28 & Yes & $\begin{array}{l}\text { Industrial, Commercial, Domestic, Civic, Public and Ecological } \\
\text { Conventions (market and technology) }\end{array}$ \\
Climent-López et al. [12] & 19 & Yes & Industrial, commercial, domestic, civic and public conventions \\
De Villanueva [31] & 8 & No & Not classified \\
Esteban-Rodríguez and Climent-López [17] & 6 & Yes & Production models \\
Esteban-Rodríguez and Climent-López [30] & 9 & Yes & Technology and market type (quality conventions) \\
Esteban-Rodríguez [19] & 4 & Yes & Technology and market type (quality conventions) \\
Esteban-Rodríguez and Climent-López [16] & 6 & Yes & Technology, market, and competition indicators (quality conventions) \\
Sánchez-Hernández et al. [18] & 21 & Yes & Products and resources \\
Szenteleki et al. [32] & 11 & Yes & Climatic indicators \\
\hline
\end{tabular}

In sum, most of the indicators are integrated into frameworks (8 of 9 publications), corresponding to 104 of 112 regional level indicators. Considering the papers mentioned in Table 5, where indicators are classified and simultaneously integrated into frameworks, four viewpoints can be highlighted: i) indicators related to products and resources of a specific territory; ii) indicators associated with climate conditions of a given region; iii) indicators classified according to known quality conventions (industrial, commercial, domestic, civic, public, and ecological); and iv) indicators grouped into technology and market types.

Given the similarity of the indicators among the four perspectives and bearing in mind the purpose of the present study, the indicators were reclassified according to the territorial, economic, and environmental dimensions. Under the territorial dimension, the exhibited indicators may be grouped into following areas territorial resources and marketing. Regarding the economic dimension, the indicators were grouped in two main dimensions - productivity and competitiveness. Lastly, the environmental dimension features indicators related to sustainability issues. Considering their geographical scope, Tables 6 to 8 summarize the most mentioned regional level indicators found in the SLR.

As the wine production is an activity that depends on the availability of 'territorial resources', the importance given by the wine regions to the measurement and impact on their businesses is crucial. Under this dimension, indicators such as 'average size of the farm per region', 'average size of the winery per region', 'number of wineries per region', 'number of brands per region' and the 'surface of the vineyard' are essential to characterize the wine industry on a regional scale.

Regarding 'marketing', indicators such as the 'use of brands' is related to an intention to associate the image of wine with a specific territory and to obtain recogni- tion as a product of origin. The 'average of stars obtained in wine guides' and the 'average awards/medals won in contests' measure the reputation based on expert assessments. Following a similar perspective, the number of 'references in specialized journals' measures the reputation in magazines which specialize in the wine industry and the 'number of results in internet search engines' analyses the popularity in a broader context. Additionally, the 'number of awards obtained by volume sold' is also a relevant indicator that reflects the importance of product quality. In summary, these previous indicators may provide crucial insights to wine regions related to their performance in terms of image and awareness. Table 6 presents the most cited indicators in the literature according to the territorial dimension.

Other indicators reported as having an important impact on the measurement of wine regions performance are those related to 'productivity'. According to the literature, the 'surface area planted with high-yielding grape varieties' indicates a search for high yields per area and per wine region. In the same way, the 'average production of wine per type/region' quantifies the average size of the wine businesses and the 'percentage of young wines' show the extent to which wine businesses are looking for wines that require less time for production. Further, high values for these indicators show the pursuit of economies of scale and subsequently reveal higher productivity.

Concerning 'competitiveness', a high percentage of vineyard area cultivated by global varieties reflects the adjustment of the suppliers to the demands of the international market. The 'percentage of vineyards controlled by cooperatives' focuses on the economic benefits of the industry and whether they are widely distributed among the local population. This indicator is an important measure of the level of collective involvement and economic cooperation within a region. 'Wine produc- 
Table 6. Territorial indicators.

\begin{tabular}{ll}
\hline Indicators & $\mathrm{N}$ \\
\hline $\begin{array}{l}\text { Number of brands per region } \\
\text { Average size of the farm per region }\end{array}$ & $\begin{array}{l}\text { Climent-López and Sánchez-Hernández [11]; Esteban-Rodríguez and Climent- } \\
\text { López [16, 30] }\end{array}$ \\
$\begin{array}{l}\text { Average size of the winery per region } \\
\text { Surface extension of vineyard (ha) }\end{array}$ & 2 Esteban-Rodríguez and Climent-López [16, 17] \\
Number of wineries per region & 2 De Villanueva [31]; Esteban-Rodríguez and Climent-López [30] \\
$\begin{array}{l}\text { Average size of brands } \\
\text { Brands of local products }\end{array}$ & 2 De Villanueva [31]; Esteban-Rodríguez and Climent-López [30] \\
$\begin{array}{l}\text { Average stars obtained by wineries in wine guides } \\
\text { within a region }\end{array}$ & 2 Esteban-Rodríguez [19]; Esteban-Rodríguez and Climent-López [30] \\
Awards/medals won by wineries in contests & 2 Climent-López and Sánchez-Hernández [11]; Climent-López et al. [12] \\
Average reference in specialized journals & 2 Climent-López et al. [12]; Sánchez-Hernández et al. [18]; Climent-López and \\
Average results obtained in internet search engines & 2 Climent-Lónez and Sánchez-Hernández [11]; Climent-López et al. [12] \\
Number of awards obtained by volume sold & 2 Esteban-Rodríguez and Climent-López [30]; Esteban-Rodríguez [19]
\end{tabular}

Table 7. Economic indicators.

\begin{tabular}{|c|c|c|}
\hline Indicators & $\mathrm{N}$ & Authors \\
\hline Wine per region $(\mathrm{hl})$ & & $\begin{array}{l}\text { Climent-López et al. [12]; Climent-López and Sánchez-Hernández [11]; De } \\
\text { Villanueva [31] }\end{array}$ \\
\hline Percentage of vineyard controlled by cooperatives & & $\begin{array}{l}\text { Climent-López and Sánchez-Hernández [11]; Climent-López et al. [12]; Sánchez- } \\
\text { Hernández et al. [18] }\end{array}$ \\
\hline Average price of the bottle per region & 2 & Sánchez-Hernández et al. [18]; Climent-López and Sánchez-Hernández [11] \\
\hline Average production of wine per region & & Climent-López et al. [12]; Climent-López and Sánchez-Hernández [11] \\
\hline $\begin{array}{l}\text { Vineyard surface area planted with global grape } \\
\text { varieties }\end{array}$ & & Sánchez-Hernández et al. [18]; Climent-López et al. [12] \\
\hline $\begin{array}{l}\text { Vineyard surface area planted with high-yielding } \\
\text { grape varieties }\end{array}$ & & Sánchez-Hernández et al. [18]; Climent-López et al. [12] \\
\hline Percentage of young wine & & Climent-López et al. [12]; Sánchez-Hernández et al. [18] \\
\hline Wineries that organized guided tours within a region & 2 & Sánchez-Hernández et al. [18]; Climent-López and Sánchez-Hernández [11] \\
\hline
\end{tabular}

tion' and 'average price per bottle' are also key indicators which when well managed can influence the business strategies of wine regions and even their national and international markets performance. Additionally, the 'number of wineries within a region that organized guided tours' may reveal a competitive advantage and a strong marketing strategy. Table 7 exhibits the indicators related to economic dimension.

Several indicators are related to 'sustainability'. For example, the 'percentage of organic certified wineries by a regulatory board' is based on the existence of labels that certify products made by processes that respect the environment and show an awareness of wine business organizations towards sustainable production processes. Furthermore, the 'percentage of planted vineyard area with rare grape varieties' provides an additional crite- rion: the designation of 'rare' alludes to certain native grape varieties that have unique characteristics, and in some cases, have practically disappeared because they have been replaced by others, whether autochthonous or foreign, so vineyards can become more productive or more competitive. Thus, the recovery of these rare varieties shows a positive attitude towards sustainability. Finally, higher values of 'vineyards planted with native varieties' reveal the intent to produce wine from local/ endogenous resources, which clearly contributes to the local development and their preservation. Table 8 synthesizes the most cited indicators from an environmental perspective.

Additionally, we reclassified the indicators according to a regional competitiveness framework into the following five basic competitiveness dimensions: pro- 
Table 8. Environmental indicators.

\begin{tabular}{|c|c|c|}
\hline Indicators & $\mathrm{N}$ & Authors \\
\hline Vineyard cultivated with rare grape varieties (\%) & & $\begin{array}{l}\text { Sánchez-Hernández et al. [18]; Climent-López and Sánchez-Hernández [11]; } \\
\text { Climent-López et al. [12] }\end{array}$ \\
\hline $\begin{array}{l}\text { Percentage of vineyard surface area planted with } \\
\text { native grape varieties }\end{array}$ & & $\begin{array}{l}\text { Climent-López and Sánchez-Hernández [11]; Climent-López et al. [12]; Sánchez- } \\
\text { Hernández et al. [18] }\end{array}$ \\
\hline Wine certified as organic by the regulatory council & 2 & Sánchez-Hernández et al. [18]; Climent-López and Sánchez-Hernández [11] \\
\hline
\end{tabular}

Table 9. Infrastructure indicators.

\begin{tabular}{ll}
\hline Indicators & $\mathrm{N}$ \\
\hline $\begin{array}{l}\text { Vineyard cultivated with rare grape varieties (\%) } \\
\begin{array}{l}\text { Percentage of vineyard surface area planted with } \\
\text { native grape varieties }\end{array}\end{array} \quad \begin{array}{l}\text { Sánchez-Hernández et al. [18]; Climent-López and Sánchez-Hernández [11]; } \\
\text { Climent-López et al. [12] }\end{array}$ \\
$\begin{array}{l}\text { Average size of the farm per region } \\
\text { Average size of the winery per region }\end{array}$ & 2 Esteban-Rodríguez and Climent-López [16, 17] \\
$\begin{array}{l}\text { Surface extension of vineyard (ha) } \\
\text { Number of wineries per region }\end{array}$ & 2 Esteban-Rodríguez and Climent-López [16, 17] \\
$\begin{array}{l}\text { Vineyard surface area planted with global grape } \\
\text { varieties }\end{array}$ & 2 De Villanueva [31]; Esteban-Rodríguez and Climent-López [30] \\
$\begin{array}{l}\text { Vineyard surface area planted with high yielding } \\
\text { grape varieties }\end{array}$ & 2 Sánchez-Hernández et al. [18]; Climent-López et al. [12] \\
\hline
\end{tabular}

ductive capital, human capital, social-cultural capital, infrastructure, and intellectual capital [following, for example, 7, and 13]. Under the infrastructure dimension, indicators such as 'Vineyard cultivated with rare grape varieties (\%)', 'Percentage of vineyard surface area planted with native grape varieties', 'Average size of the farm per region', and 'Surface extension of vineyard (ha)' demonstrate the importance of existing infrastructure for regional competitiveness (see Table 9).

The productive capital dimension covers aspects such as economic development, stability, or market size. In our study this dimension includes indicators such as 'Average production of wine per region', 'Wine per region (hl)', 'Percentage of young wine' and 'Average price of the bottle per region' (see Table 10).

For the social and institutional capital that should include variables relating to the efficiency of public administration or the legal framework, in our study an indicator 'Percentage of vineyard controlled by cooperatives' could be identified [11, 12, 18].

Finally, Indicators as, e.g., 'number of brands per region', 'wineries that organized guided tours within a region', 'average stars obtained by wineries in wine guides within a region', and 'wine certified as organic by the regulatory council', were classified under the innovation and intellectual dimension (see Table 11).

\section{CONCLUSIONS, IMPLICATIONS, LIMITATIONS, AND FUTURE RESEARCH}

Given the increasing importance of the wine industry, and especially of well-managed wine regions, conducting a study to identify indicators and competitiveness frameworks with impact on performance at the regional level seemed an interesting and challenging research task. Based on an SLR, we sought to identify the main performance indicators used at regional level to support decision-making in the wine industry.

The results document that there is a limited number of research works identifying indicators with impact on the performance of wine regions, and even fewer studies including indicators in an integrated approach to measure the different dimensions of wine regions performance. Thus, our research contributes to the literature by identifying indicators according to a regional competitiveness framework grouped into five main dimensions: productive capital, human capital, social-cultural capital, infrastructure and intellectual capital. According to this SLR, the indicators grouped and ranked under this framework are the most referred to and are used to address the overall performance of the wine industry. Moreover, most of them are used in highly competitive PDO regions. As such, they could be clustered as the 
Table 10. Productive capital indicators.

\begin{tabular}{ll}
\hline Indicators & $\mathrm{N}$ \\
\hline Wine per region $(\mathrm{hl})$ & $3 \begin{array}{l}\text { Climent-López et al. [12]; Climent-López and Sánchez-Hernández [11]; De } \\
\text { Villanueva [31] }\end{array}$ \\
$\begin{array}{l}\text { Average price of the bottle per region } \\
\text { Average production of wine per region }\end{array}$ & 2 Sánchez-Hernández et al. [18]; Climent-López and Sánchez-Hernández [11] \\
Percentage of young wine & 2 Climent-López et al. [12]; Climent-López and Sánchez-Hernández [11] \\
\hline
\end{tabular}

Table 11. Innovation and intellectual capital indicators.

\begin{tabular}{|c|c|c|}
\hline Indicators & $\mathrm{N}$ & Authors \\
\hline Number of brands per region & & $\begin{array}{l}\text { Climent-López and Sánchez-Hernández [11]; Esteban-Rodríguez and Climent- } \\
\text { López }[16,30]\end{array}$ \\
\hline Wineries that organized guided tours within a region & 2 & Sánchez-Hernández et al. [18]; Climent-López and Sánchez-Hernández [11] \\
\hline Average size of brands per region & 2 & Esteban-Rodríguez [19]; Esteban-Rodríguez and Climent-López [30] \\
\hline Brands of local products & 2 & Climent-López and Sánchez-Hernández [11]; Climent-López et al. [12] \\
\hline $\begin{array}{l}\text { Average stars obtained by wineries in wine guides } \\
\text { within a region }\end{array}$ & & Climent-López et al. [12]; Climent-López and Sánchez-Hernández [11] \\
\hline Awards/medals won by wineries in contests & & $\begin{array}{l}\text { Climent-López et al. [12]; Sánchez-Hernández et al. [18]; Climent-López and } \\
\text { Sánchez-Hernández [11] }\end{array}$ \\
\hline Average reference in specialized journals & 2 & Climent-López and Sánchez-Hernández [11]; Climent-López et al. [12] \\
\hline Average results obtained in internet search engines & 2 & Climent-López and Sánchez-Hernández [11]; Climent-López et al. [12] \\
\hline Number of awards obtained by volume sold & & Esteban-Rodríguez and Climent-López [30]; Esteban-Rodríguez [19] \\
\hline Wine certified as organic by the Regulatory Council & 2 & Sánchez-Hernández et al. [18]; Climent-López and Sánchez-Hernández [11] \\
\hline
\end{tabular}

main dimensions and indicators to be used at regional level to support decision-making in the wine industry.

Under the regional competitiveness framework, the only basic competitiveness dimension for which we have not identified any indicators was that of human capital. This dimension should incorporate indicators related to the efficiency of the labour market, basic and higher education, and ongoing training.

To achieve the target of regional competitiveness and to increase the well-being of the population in a certain region, it is essential to fulfil the basic dimensions of regional competitiveness. Our results document that infrastructures, intellectual capital and productivity are dimensions that are given importance in terms of regional competitiveness in the wine industry. However, the same importance is not given to the dimensions of human and socio-cultural capital.

To improve the quality of life of a region, e.g., represented by means of the gross regional product, it is essential to increase labour productivity and the employment rate, which is difficult to accomplish without including the human capital dimension.

Industry-wise, this paper contributes to the development of a meaningful and useful framework to assess collective wine business organizations/wine regions by means of performance indicators. Nevertheless, regional specificities and their different business units must be considered when designing and proposing performance indicators in a framework. As referred to in the document, certain regions based their competitiveness on PDOs, which might aggregate several of those indicators. From an academic viewpoint, this paper highlights the main research areas that require more attention in the future and might help researchers to update knowledge on this field.

Based on these regional indicators, future research could focus on developing studies/indicators related to National Board Commissions in the wine industry.

\section{REFERENCES}

[1] B. Rugani, I. Vázquez-Rowe, G. Benedetto, E. Benetto, A comprehensive review of carbon footprint analysis as an extended environmental indicator in the wine sector, J. Cleaner Prod. 54(1) (2013) 61-77.

[2] C. Maurel, A. Ugaglia, B. Del'homme, Evolution of the concept of performance in the wine industry: 
A literature review, Int. J. Entrepreneurship Small Bus. 32(1/2) (2017) 254-279.

[3] OIV (International Organisation of Vine and Wine) OIV State of the World Vitivinicultural Sector in 2019. Accessed May 7, 2020 at http://www. oiv.int/en/oiv-life/current-situation-of-the-vitivinicultural-sector-at-a-global-level (accessed at 07/05/2020).

[4] R. Bandinelli, D. Acuti, V. Fani, B. Bindi, G. Aiello, Environmental practices in the wine industry: an overview of the Italian market, Br. Food J. 122(5) (2020) 1625-1646.

[5] T. Atkin, D. Wilson, L. Thach, J. Olsen, Analyzing the impact of conjunctive labeling as part of regional wine branding strategy, Wine Econ. Policy. 6(2) (2017) 155-164.

[6] M. Del Giudice, Z. Khan, M. De Silva, V. Scuotto, F. Caputo, E. Carayannis, The microlevel actions undertaken by owner-managers in improving the sustainability practices of cultural and creative small and medium enterprises: A United Kingdom-Italy comparison, J. Organizational Behav. 38(9) (2017) 1396-1414.

[7] J. Vega, J. Azorín, A. Segura, M. Yago, A new measure of regional competitiveness, Appl. Econ. Anal. 27(80) (2019) 108-126.

[8] P. Annoni, K. Kozovska, EU regional competitiveness index 2010, Joint Research Centre, Scientific and Technical Reports. (2010).

[9] D. Borozan, J. Strossmayer, Regional competitiveness: some conceptual issues and policy implications. Interdiscip. Manage. Res. 4 (2008) 50-63.

[10] S. Flores, What is sustainability in the wine world? A cross-country analysis of wine sustainability frameworks, J. Cleaner Prod.. 172 (2018) 2301-2312.

[11] E. Climent-López, J. Sánchez-Hernández, La théorie des conventions en géographie économique: Un éclairage apporté par l'application à l'industrie espagnole du vin, Géographie, Economie, Société. 17(1) (2015) 25-50.

[12] E. Climent-López, J. Sánchez-Hernández, C. Canto-Fresno, J. Alonso-Santos, S. Ramírez-García, V. Rodero-González, E. Ruiz-Budría, Measuring quality conventions in the food industry: Applications to the wine sector in Spain, Geoforum. 56 (2014) 148-160.

[13] I. Lengyel, The pyramid model: enhancing regional competitiveness in Hungary, Acta Oeconomica. 54(3) (2004) 323-342.

[14] A. Goncharuk, Exploring the factors of efficiency in German and Ukrainian wineries, J. Wine Res. 28(4) (2017) 294-312.
[15] J. Mota, A. Moreira, R. Costa, S. Serrão, V. PaisMagalhães, C. Costa, Performance indicators to support firm-level decision-making in the wine industry: a systematic literature review, Int. J. Wine Bus. Res. 33(2) (2020) 217-237.

[16] S. Esteban-Rodríguez, E. Climent-López, Los mundos de producción de las denominaciones de origen protegidas del vino en España: Disparidad de convenciones tecnológicas y comerciales, Economía Agraria y Recursos Naturales. 17(1) (2017) 101-125.

[17] S. Esteban-Rodríguez, E. Climent-López, Modelos productivos de las DOP de vino en España, Cuadernos Geográficos. 57(1) (2018a) 259-282.

[18] J. Sánchez-Hernández, E. Climent-López, S. Ramírez-García, V. Rodero-González, B. Loscertales-Palomar, C. Canto-Fresno, Clasificación de las Denominaciones de Origen vinícolas en la tipología de los mundos de producción: una aplicación al caso español, Cuadernos Geográficos. 56(2) (2017) 263-282.

[19] S. Esteban-Rodríguez, Changes in Protected Designations of Origin in the Spain Wine Sector: Movements between worlds of production, Boletín de la Asociación de Geógrafos Españoles. 74 (2017) 627-633.

[20] D. Vergamini, F. Bartolini, P. Prosperi, G. Brunori, Explaining regional dynamics of marketing strategies: The experience of the Tuscan wine producers, J. Rural Stud. 72 (2019) 136-152.

[21] D. Denyer, D. Tranfield, Producing a systematic review, in: D. Buchanan, A. Bryman (Eds.), The Sage Handbook of Organizational Research Methods, Sage, London, 2009, pp. 671-689.

[22] D. Tranfield, D. Denyer, P. Smart, Towards a methodology for developing evidence-informed management knowledge by means of systematic review, Br. J. Manage. 14(3) (2003) 207-222.

[23] H. Snyder, Literature review as a research methodology: An overview and guidelines, J. Bus. Res. 104 (2019) 333-339.

[24] A. Bonn, M. Cho, H. Um, The evolution of wine research: A 26 year historical examination of topics, trends and future direction, Int. J. Contemporary Hospitality Manage. 30(1) (2017) 286-312.

[25] R. Light, D. Pillemer, Summing Up: The Science of Reviewing Research, Harvard University Press, Cambridge, MA, 1984.

[26] P. Silva, A. Moreira, A systematic review of the literature on industrial divestment, Baltic J. Manage. 14(3) (2019) 443-461.

[27] V. Braun, V. Clarke, Using thematic analysis in psychology, Qual. Res. Psychol. 3(2) (2006) 77-101. 
[28] M. Jones, N. Coviello, Y. Tang, International entrepreneurship research (1989-2009): a domain ontology and thematic analysis, J. Bus. Venturing. 26(6) (2011) 632-659.

[29] C. Ribau, A. Moreira, M. Raposo, SME internationalization research: mapping the state of the art, Canadian J. Administrative Sci. 35(2) (2018) 280303.

[30] S. Esteban-Rodríguez, E. Climent-López, Les appellations d’origine protégée du vin en Espagne, d'après la théorie des mondes de production: Une approche quantitative, Annales de Géographie. 3(721) (2018b) 279-306.

[31] B. De Villanueva, Caracterización del boom vitivinícola en Mendoza (Argentina), 1904-1912, Mundo Agrario. 9(13) (2009).

[32] K. Szenteleki, M. Ladányi, M. Gaál, G. Zanathy, G. Bisztray, Climatic risk factors of central Hungarian grape growing regions, Appl. Ecol Environ. Res. 10(1) (2017) 87-105.

[33] R. Merli, M. Preziosi, A. Acampora, Sustainability experiences in the wine sector: toward the development of an international indicators system, J. Cleaner Prod. 172 (2018) 3791-3805. 